\title{
Ismailova S.R.
}

DOI: 10.25108/2304-1730-1749.iolr.2018.54.119-131

\section{National interest in the system of political realism}

Abstract: The conceptual silhouette of the theory of political realism acquires attractiveness, grace and harmony precisely because it is formed on the basis of the notion of 'national interest.' However, the grace of the form of the concept of 'national interest' did not add attractiveness to its content, which would unite around it representatives of different approaches in international political science.

Theorists of the liberal and idealistic paradigm and practices inspired by their ideas are ready to agree with the existence of national interests only on condition that their content should be recognized as moral norms and global problems of our time. The protection of sovereignty and the resulting desire for power in the increasingly interdependent world are losing their significance ever more.

Keywords: national interest; political realism; a state; international interests; public interest.

Political realism regards 'national interest' as an objective reality based on the originality of the geographical position of the state and the resulting economic, political and cultural development, on the one hand, and on the characteristics of human nature, on the other.

According to H. Morgenthau, 'national interest' is a stable basis of the state international policy. The geopolitical position of the state and its environment, the nature of those threats and challenges to which it opposes, as well as the sociocultural traditions of its population and the structural features of its foreign trade

\footnotetext{
'Ismailova Sevinj Rauf qizi - Doctoral Candidate of the Academy of Public Administration under the
} President of the Republic of Azerbaijan, PhD in Law (Azerbaijan). E-mail: sevism@ @ambler.ru 
do not change every day and therefore do not depend on arbitrariness or subjective preferences of 'sovereigns.' From his point of view, 'national interest' contains two main elements: central (permanent) and secondary (volatile). The secondary element is nothing more than a concrete form, which the fundamental 'national interest' takes in space and time. The central interest consists of three factors: the nature of the interest to be protected, the political environment which interest operates in, and the rational necessity that limits the choice of goals and means [7, pp. 163-164].

Representatives of political realism believe that 'national interest' is quite susceptible to rational thinking of statesmen. The latter must proceed from the premise that a good policy is a rational policy based on a correctly understood 'national interest.' This implies an awareness of the fact that the distinctive quality of politics, including the international one, is the struggle for power. The objective contradiction faced both by the researcher and the 'sovereign' is that the nature of power itself prevents "deep rationalization generates moral dilemmas, political risks and intellectual surprises". The essence of the rational approach involves recognizing this feature of political relations, which means the need to take it into account and use it intelligently on the basis of 'national interest.' The rational approach delineates the scope of what is possible in politics, points to obstacles of an objective nature that do not allow one or another speculative scheme to be imposed on the resisting reality, however attractive the scheme may be. Any attempts to eliminate these obstacles, whether they are dictated by concern for practical results, aspiration to reliable foresight or overcoming the uncertainty of politics, are doomed to imminent failure, since they proceed from what is desirable, instead of realizing what is possible. Moreover, such attempts are not only utopian, but also dangerous, as they are often based on moral or ideological preferences [7, p. 168]. 
According to $\mathrm{H}$. Morgenthau, although the essence of politics is the desire to establish moral values through power, this does not mean that a politician can claim knowledge of what is morally conditioned for a 'state' in a particular situation. The "carefree assumption that the bearer and exponent of the moral good is one nation and the one who professes evil is another, is untenable not only morally but also intellectually. Practically, such an assumption leads to a distortion of estimates, to the generation of insanity of violent crusades". As for ideology, "foreign policy, seeking the triumph of a single ideology, has always led to fanatical and bloody wars..." [7, pp. 164-165]. Moral policy proceeds from the need of harmonization and compromises in protecting the 'national interests' of states in the international arena, from the desire to achieve 'universal interests,' which is incompatible with the rivalry of political ideologies [7, p. 174].

According to the statements of representatives of political realism, 'national interest' is fundamentally different from 'public interest.' If the former exists in an anarchic international environment, the latter is linked to the system of laws that regulate domestic politics. In other words, unlike 'public interest', the notion of 'national interest' refers to the sphere of the state foreign policy.

It should be noted that advocates of a strict understanding of the category of 'national interest' both in theory and political practice invariably adhere to this division. "Just as the notion of 'public interest' was used to increase and protect the public good against internal challenges", one of the followers of the theory of political realism writes, "the notion of 'national interest' was used to advance the goals of foreign policy" [6, p. 13; 8, p. 16; 12, p. 2].

Thus, the conceptual silhouette of the theory of political realism acquires attractiveness, grace and harmony precisely because it is formed on the basis of the notion of 'national interest.' However, the grace of the form of the concept of 'national interest' did not add attractiveness to its content, which would unite around it representatives of different approaches in international political science. 
Critics doubted the statement of $\mathrm{H}$. Morgenthau that "there is only one categorical imperative, only one criterion of reasoning, the only principle of action: national interest". Opponents of realism refused to take on faith the most important thing in it - the objectivity of the content of 'national interest.' Sceptics were found even in the camp of staunch adherents of political realism. According to R. Aaron, the pluralism of the goals, means and resources that different individuals and groups have inside a state does not form any resultant and does not allow us to evaluate 'national interest' as a criterion of analysis or an ideal for a politician [1, p. 101]. The foreign policy of a state, according to Aaron, is expressed in the actions of its leaders who have certain degrees of freedom in choosing goals. At the same time, ideology, ambition, temperament, and other qualities of leaders are of great importance. However, the position of state leaders determines their desire to create the impression that the basis of all their actions is national interest [1, pp. 97-102].

Some followers of Aaron go further, believing that, although the interest is objective, but, in fact, it is unknowable. For a scientist who proceeds from an objective interest in explaining the behaviour of people and social communities, the danger consists in the almost absolute inevitability of slipping into the path of arbitrary 'construction' of interests. According to a number of scientists, there is a risk to replace the subjectivity of those studied by a sociologist, by his own subjectivity [4, p. 26]. A similar opinion is held also by the famous French expert in the field of international relations J.-B. Duroselle. 'It would be, of course, good,' he writes, 'if there was an opportunity to determine an objective national interest. Then it would be quite easy to explore international relations by comparing the national interest offered by the leaders and the objective national interest. The trouble, however, is that any reflection on objective national interest is subjective' [5, p. 88]. 
According to A. Wolfers, 'national interest' can mean different things for different people, moreover, it is capable of giving an attractive appearance to a mistaken policy [11, p. 147].

Theorists of the liberal and idealistic paradigm and practices inspired by their ideas are ready to agree with the existence of national interests only on condition that their content should be recognized as moral norms and global problems of our time. The protection of sovereignty and the resulting desire for power in the increasingly interdependent world are losing their significance ever more [10, pp. $38-43$ ]. It is easy to see that the protection of moral values and responses to global threats go far beyond national borders. Hence the statement that the main task facing today democratic states is not the protection of national interests, but concern for moral principles and human rights [3, pp. 5-7].

Some researchers come to the conclusion that 'national interest' is nothing more than a myth, a symbol used by politicians to justify their actions and hide their own mistakes and fight with the opposition [2, p. 3]. Dario Battistella believes that the foregoing allows us to state that 'national interest' is 'not so much an instrument of analyzing international politics as a concept for internal political and ideological use' [2, p. 3]. This conclusion is fully consistent with the conclusion of J. Rosenau, made as far back as in 1971: 'Regardless of the provisions cited in support of this concept and despite its apparent utility, the national interest has not become the analytical tool that promised to become once' [9, p. 248].

\section{References}

1. Aaron R. Paix et Guerre entrée / R. Aaron - Paris: Calmann-Levy, 1984.

2. Battistella D. Théories des relations internationales, Paris, Sciences Po les Presses, 1995. 
3. Blair T. «Doctrine of the International Community». Address by British Prime Minister Tony Blair to Economic Club, Chicago, 111. 1999. 22 April.

4. Derriennic J.-P. Esquisse de problematique pour une sociologie des relations internationales. Grenoble, 1977.

5. Duroselle J.-B. Tout empire perira. Une vision theoriqu des relations scene international. Paris: Armand Colin, 1992.

6. Kratochwil F. Of the Notion of Interest in International Relation // International Organization. Vol. XXXIV. Winter 1982.

7. Morgenthau H. Politics among Nations. The Struggle for Power and Peace. Boston : McGraw-Hill Higher Education, 2006.

8. Nuechterlein D.E. America Recommitted: United States National Interests in a Reconc tured World. Pexington, 1991.

9. Rosenau J. The National Interest: Normative Foundation // Review of Politics. Vol. 43. 1986. Autumn.

10. Smouts M.-C. (sous la dir. de). Les nouvelles relations internationales. Pratiques et theories. P., 1998.

11. Wolfers A. Discord and Collaboration. Essay of International Politics. Baltimore, 1962.

12. Yarger R.H. and Barber G.F. The U.S. Army War College Methodology for Determining Interests and Levels of Intensity. Carlisle Barraks, 1997. Wolfers A. Discord and Collaboration. Essay of International Politics. Baltimore, 1962. 